UDC: $159.923+616.89$

DOI: https://doi.org/10.24195/2414-4665-2017-1-11

\author{
Anna Lisovenko, \\ post-graduate student, Department of General and Differential Psychology, \\ South Ukrainian National Pedagogical University after K. D. Ushynsky, \\ 4, Fontanska Doroha, Odessa, Ukraine
}

\title{
ENVY AND PERFECTIONISM: THE INTERRELATIONSHIP OF THE CONCEPTS
}

The article deals with the results of theoretical and empirical research of the features of perfectionism manifested by individuals prone to envy in different degrees. Envy is considered to be stable individual property caused by frequent comparing oneself with others not in personal favor, characterized by subjective feelings of decreasing self-worth and displayed in passionate desire to get what the object of comparison has. Perfectionism as a desire to be perfect and impeccable is analyzed as well. The special complex of methods to define the ratio between proneness to envy and perfectionism included the technique "Differential diagnosis of personality tendency to envy" by O. Sannikova, A. Lisovenko and P. Hewitt and R. Flett's "Multidimensional Perfectionism Scale". The significant positive correlations between the indicators of envy and perfectionism have been detected. It has been theoretically substantiated and empirically confirmed that envious personalities are prone to socially oriented and prescribed perfectionism.

Keywords: envy, tendency to envy, perfectionism, property of the individual, personality.

\section{Introduction}

In the contemporary conditions of rapid social and socio-cultural transformations even such basic personality characteristics as striving to self-improvement and ideals, accepted by an individual and his/her environment, undergo some changes. It is well-known that the direction of personal growth depends on the example, ideal to follow, which an individual chooses. Social and cultural values of modern society, such as the cult of material success, the rich and famous, strength and power, competitiveness and individualism uniting into macrosocial factors, plays a significant role in the development of the phenomenon of perfectionism and envy. Thus, the cult of perfection turns into a mass, feverish pursuit of prestige attributes of high social status.

In the world of television, advertisements, glossy magazines, and internet social networks many reasons for social comparison appear. Permanent idealized contemplation of others' life (vivid, luxurious, rich-looking) generates envy of observers and a certain dissatisfaction because of the frequent comparison of themselves with the object of idealization. Envy is determined by the most valued things in the society or a social group, because social values are the criteria of social hierarchy. Furthermore, envy may occur towards those who achieved some significant advantages in certain spheres (spiritual, social, psychological, physical, material, etc.).

The phenomenon of envy has attracted the interest of philosophers and religious leaders, having been theoretically studied in different directions of personality psychology: classical (S. Freud, M. Klein, O. Kernberg) and humanistic psychoanalysis (E. Fromm), individual psychology (A. Adler), analytical psychology (C. Jung), sociocultural theory (K. Horney), humanistic (A. Maslow) and existential, psychology (V. Frankl), etc.

Empirical studies of envy appeared only in recent decades in the works of K. K. Muzdybayeva,
V. O. Labunska, L. S. Arkhangelska, T. V. Beskova, R. M. Shamionova, N. V. Gorshenina and others. Envy is understood in different ways but the definitions are somewhat similar; it is considered as unpleasant emotion (emotional condition, feeling), attitude towards another person who, in the opinion of subject of envy, has certain advantages, features, or is in a favorable position. In other words, envy is a severe experience of one's own imperfection, person's reaction to obvious or subjective preference of another individual over himself/herself.

In this work, envy is considered as a stable personality trait, often caused by comparing oneself with others not in one's own favor, which is also characterized by subjective feeling of reduction of self-worth, manifested by the desire to possess the advantages of the object of comparison (or to deprive him/her of these benefits). It is also accompanied by specific emotions (anger, irritation, fury, hostility, dissatisfaction, disappointment, frustration, sadness, depression etc.); certain thoughts and ideas about oneself and others (thoughts of discontent with one's own state, status, qualities, and life in general, about one's own humiliation, thinking about inferiority, the desire to "be equal", or even thoughts of revenge); manifestations of specific behavior (rivalry or competition, ill behavior, proneness to gossip, sarcasm, ignoring, dastardly deeds against the object of envy). In the structure of envy the following components can be distinguished: emotional (EE), cognitive (CE), behavioral (VE), motivational (ME), control and regulatory (CRE) and instructional (IE). The study of their manifestation makes it possible to identify the field in which person's envy is eminently expressed: in emotions, thoughts or behavior, whether there is motivation and envy attitude, and whether envy is controlled [1].

Thus, we understand envy as an adequate or inadequate short-term reaction, which occurs in certain situa- 
tions, as more or less prolonged mental state, and as a stable feature of a personality - proneness to envy.

Despite the dominant negative connotation of envy, functionally envy (short-term) can also play a positive role in promoting awareness of one's own needs, competitive spirit, desire for success, striving for changes.

It should be noted that envy and perfectionism (striving for excellence) are the metaphysical concepts of the "soul and spirit deepest foundations", and serve as motivation of actions in the structure of needs for selfaffirmation and self-perfection.

Perfectionism includes a number of interrelated features, some of which contribute to exclusion, while others are generally adaptive. Perfectionism is considered to be a characteristic feature of gifted, academically successful, diligent students [2]. However, current research studies suggest that excessive perfectionism is one of the main factors of personality's affective sphere disorders, which results in frequent experience of dissatisfaction, depression, anxiety, shame and guilt; it is also manifested in the inability to act, slow performance and chronic fatigue resulted from the establishment of high standards in all kinds of activities; in interpersonal relations in can be expressed in conflicts and breaks due to excessive demands and comparisons with others, envy and jealousy. Besides, neurotic perfectionism results in anxiety, depression, low self-esteem, alcoholism, and drug-addiction [4].

Potentially perfectionism can cause both incredible satisfaction with one's own activities, achievements, personal development and intense frustration and disappointment. D. Hamachek distinguishes healthy (constructive) and pathological (neurotic, destructive) perfectionism [5]. Healthy perfectionism involves establishing high personal standards, challenging goals and enjoying the process of their achieving. Neurotic perfectionism is manifested in the individual's desire to meet unreal exaggerated standards and aims, accompanied by the fear of failure, unacceptability of errors, critical evaluation of self and others, dissatisfaction of work and life.

The researchers P. Hewitt and R. Flett, basing on the results of clinical observations, created "Multidimensional Perfectionism Scale", which contains three components: self-oriented perfectionism; others-oriented perfectionism, and socially prescribed perfectionism. According to their definition, perfectionism is a desire to be perfect, impeccable in everything [2].

Basing on the scientific literature review, we suppose that person's desire to be the best in everything hypothetically can turn into contempt for people with the lower level of spiritual, social and material status on one hand, and into envy towards those, who has some advantages, on the other hand.

Thus, the paper aims to present the results of the study of the ratio between the indices of proneness to envy and perfectionism.

Research methods

To diagnose tendency to envy the original test questionnaire "Differential diagnosis of personality's proneness to envy" and the questionnaire "Social attitudes towards envy" by O. Sannikova, A. Lisovenko [1] were used. In order to examine perfectionism P. Hewitt and R. Flett's "Multidimensional Perfectionism Scale" was applied.

The study was conducted in Ushynsky University (Odesa). The students of $1^{\text {st }}$ and $2^{\text {nd }}$ years of studying majoring in different specializations, as well as full-time and part-time students of the Department of Postgraduate Retraining in the specialty "Psychology" took part in the experiment. The respondents were aged from 17 to 45 years; total number - 253 students. The data were processed using quantitative (Spearman correlation method) and qualitative [3] (the method of "aces" and "profiles", Student's t- test) analysis.

\section{Discussion}

Table 1 shows the significant correlations between indicators of envy and perfectionism.

Table 1.

Significant correlations between indicators of envy and perfectionism

\begin{tabular}{|l|c|c|c|c|c|c|c|}
\hline & $\mathrm{AE}$ & $\mathrm{EE}$ & $\mathrm{CE}$ & $\mathrm{BE}$ & $\mathrm{ME}$ & $\mathrm{CRE}$ & $\mathrm{IE}$ \\
\hline Self-oriented perfectionism & & & & $147^{*}$ & & & \\
\hline Others-oriented perfectionism & $244^{* *}$ & $197^{* *}$ & $232^{* *}$ & $158^{*}$ & $239^{* *}$ & $182^{* *}$ & $237^{* *}$ \\
\hline Socially prescribed perfectionism & $361^{* *}$ & $267^{* *}$ & $412^{* *}$ & $284^{* *}$ & $302^{* *}$ & $213^{* *}$ & $377^{* *}$ \\
\hline General perfectionism & $294^{* *}$ & $198^{* *}$ & $298^{* *}$ & $272^{* *}$ & $306^{* *}$ & $141^{*}$ & $312^{* *}$ \\
\hline
\end{tabular}

Note: 1) zeros and commas omitted; 2 ) marking ** - significance of correlation at the $1 \%$ level, ${ }^{*}$ - significance of correlation at the $5 \%$ level; 3) components of envy: $\mathrm{AE}$ - attitude-related, $\mathrm{EE}$ - emotional, $\mathrm{CE}$ - cognitive, $\mathrm{BE}$ - behavioural, $\mathrm{ME}$ - motivational, $\mathrm{CRE}$ - control-regulating, GE general envy index.

The correlation analysis has shown the presence of significant positive correlations (primarily at $1 \%$ ) between all indicators of envy and almost all perfectionism markers (except for self-oriented perfectionism). The highest value of correlation at $1 \%$ level was found among socially prescribed perfectionism and attitude-related, cognitive and general indices of envy. General perfectionism has the most significant correlations with attitude-related, cognitive and motivational components of envy, which involves attitudes, thoughts and motivations of envious nature.

Based on the data obtained using original techniques the respondents can be divided into the following two groups with the help of the method of "aces" [3]: 1) the 
students with the maximum values of general envy index, 2) the ones who have the minimum value of general envy index. Previously, the results of the empirical study were transmitted into percentiles. The profiles of perfectionism markers with maximum (General perfectionism max, $\mathrm{n}=$ 64) and minimum (General perfectionism min, $n=66$ ) values of general index of envy are shown in Figure 1.

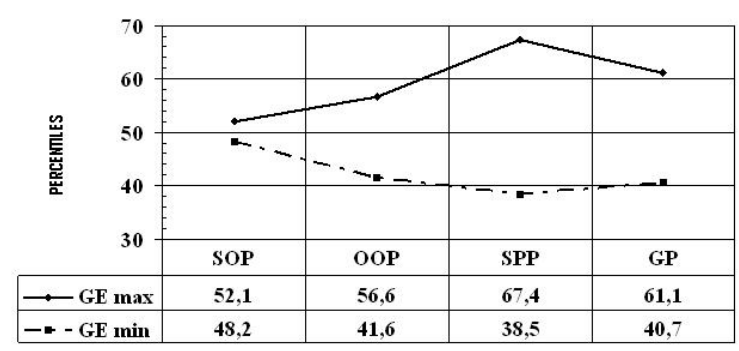

Fig. 1. Scale profiles of perfectionism in the groups with maximum and minimum value of tendency to envy.

Notes: SOP - self-oriented perfectionism, OOP - other-oriented perfectionism, SPP - socially prescribed perfectionism, GP - general perfectionism.

The analysis of the profiles of the members of the aforementioned groups indicates that there are some differences between them. They were statistically examined using Student t-test, and most of them were significant.

The profile analysis (Fig. 1) indicates that the members of the group with maximum values of general indicator of envy have increased values of all parameters of perfectionism (especially socially prescribed) and the members of the group with minimum value of general indicator of envy have reduced values of perfectionism. In general, the profile data show the opposite tendencies in the manifestation of the investigated personality traits of the respondents. Thus, according to the research results, the individuals with greater proneness to envy are characterized by the following features:

- average level of self-oriented perfectionism that involves establishing high standards to oneself, and goals which can be hardly achieved;

- slightly increased level of perfectionism focused on others, which involves establishing high standards for others, being demanding of others, intolerance, unwillingness to forgive other people's mistakes;

- high level of socially prescribed perfectionism, which is manifested in person's belief that others have extremely high and unrealistic expectations from him/her and establish difficult or impossible standards to follow, but at the same time it is necessary to gain the approval and acceptance to avoid negative assessment. People with this type of perfectionism are not interested in the practical result of a deal, but in the acceptance, approval, admiration, affirmation they can get coping with work or achieving a goal successfully. This type of perfectionism is a kind of neurotic, as such people's desire for perfection is forced, socially imposed.

The results of the research are in line with the idea of I. Hrachova who believes that in order to feel confident, be interesting an individual needs constant approval of his/her actions even by strangers, making others feel envy [2].
Thus, we can conclude that envious individuals are prone to neurotic, socially oriented and prescribed perfectionism, excessive desire for the unattainable and sometimes even false ideal. In this regard, it can be assumed that frequent social comparisons make people dependent on external assessments and standards, make them pay more attention and efforts not to the disclosing of their own abilities, but to "being the best among others and not worse than they are". These individuals are socially successful to onlookers but inside they may feel dissatisfied, because they are forced to follow outside, socially prescribed, imposed values and ideals that do not always meet their own desires. Consequently, they may have the feeling of inconsistency of other people's requirements: they do even not realize that they do what other people want them to do.

\section{Conclusions}

Thus, envy is considered to be a stable individual property caused by frequent comparing oneself with others not in personal favor, characterized by subjective feelings of decreasing self-worth and manifested in passionate desire to get what the object of comparison has.

In this research, perfectionism is understood as the desire to be perfect in everything.

The special complex of methods to define the ratio between proneness to envy and perfectionism included the technique "Differential diagnosis of personality tendency to envy" by O. Sannikova, A. Lisovenko and P. Hewitt and R. Flett's "Multidimensional Perfectionism Scale".

The significant positive correlations between the indicators of envy and perfectionism have been revealed. The profiles of perfectionism indices in the groups of the respondents with maximum and minimum values of the general indicator of envy have been analyzed. It has been theoretically substantiated and empirically confirmed that envious personalities are prone to socially oriented and prescribed perfectionism.

Further research studies involve examination of the bonds between proneness to envy and social frustration. 


\section{REFERENCES}

1. Sannikova, O. P., Lisovenko, A. F. Naukovometodychnyi tvir «Kompleks psykhodiahnostychnykh metodyk doslidzhennia zazdroshchiv osobystosti: «Metodyka "Sotsialni nastanovy osobystosti vidnosno zazdroshchiv»; "Protsedura «Shkala samootsinky pokaznykiv zazdrisnosti»; 《Test-metodyka "Dyferentsialna diahnostyka skhylnosti osobystosti do zazdroshchiv (DIZA)» [A. S. Scientific-methodical work "A complex of psychodiagnostic methods for the study of personality's envy: "Methods of Social attitudes of the individual regarding envy"; Procedure "Scale selfassessment indicators of envy"; Test technique "Differential diagnosis of the propensity of a person to envy»]. [in Ukrainian].

2. Grachova, I. I. (2006). Adaptatsiya metodiki «Mnogomernaya shkala perfektsionizma» P. KH'yuitta i

\section{ЛІТЕРАТУРА}

1. А. с. Науково-методичний твір «Комплекс психодіагностичних методик дослідження заздрощів особистості: «Методика «Соціальні настанови особистості відносно заздрощів»; «Процедура «Шкала самооцінки показників заздрісності»; «Тест-методика «Диференціальна діагностика схильності особистості до заздрощів (ДІЗА)» / О. П. Саннікова, А. Ф. Лісовенко. - № 67445; заяв. 29.06.2016; реєстрац. 26.08.2016. - 96 с.

2. Грачёва И.И. Адаптация методики «Многомерная шкала перфекционизма» П. Хьюитта и Г. Флетта / И.И. Грачёва // Психологический журнал. - 2006.
G. Fletta [Adaptation of the methodology "The multidimensional scale of perfectionism" by P. Hewitt and G. Flett]. Psikhologicheskiy zhurnal - Psychological journal, 6, (Vol. 27), 74-89 [in Russian].

3. Sannikova, O. P. (1995). Emotsionalnost v strukture lichnosti [Emotionality in the personality structure]. Odessa: Khors [In Russian].

4. Yasnaya, V. A., Yenikolopov, S. N. (2007). Perfektsionizm: istoriya izucheniya i sovremennoye sostoyaniye problemy [Perfectionism: the history of the study and the current state of the problem]. Voprosy psikhologii-Issues of psychology, 4 [in Russian].

5. Hamachek, D. E. (1978). Psychodynamics of normal and neurotic perfectionism. Psychology, 15, 27-33 [in English].

Том 27, №6. - С. 74-89.

3. Санникова О. П. Эмоциональность в структуре личности / Ольга Павловна Санникова. - Одесса: Хорс, 1995. - 364 c.

4. Ясная В. А., Ениколопов С. Н. Перфекционизм: история изучения и современное состояние проблемы / В. А. Ясная, С. Н. Ениколопов // Вопросы психологии. 2007. № 4

5. Hamachek D. E. Psychodynamics of normal and neurotic perfectionism / D. E. Hamachek // Psychology. 1978. - V. 15. - P. 27-33.

\section{Анна Федорівна Лісовенко, аспірант кафедри загальної та диференціальної психології, Південноукраӥнський національний педагогічний університет імені К. Д. Уиинського, вул. Фонтанська дорога, 4, м. Одеса, Украӥна}

\section{ЗАЗДРІСНІСТЬ ТА ПЕРФЕКЦІОНІЗМ: СПІВВІДНОШЕННЯ ПОНЯТЬ}

Соціально-культурні цінності сучасного суспільства, наприклад, культ матеріального успіху і економіки споживацтва, культ багатих і відомих, культ сили і влади, конкурентність та індивідуалізм, об'єднуючись у макросоціальні фактори, відіграють суттєву роль у розвиткові феномену перфекціонізму та заздрощів. У світі телебачення, реклами, глянцевих журналів, інтернету з'являється безліч стимулів до соціального порівняння. Постійне споглядання ідеалізованого чужого життя (яскравого, багатого, насиченого на вигляд) породжує у спостерігачів заздрість та певне невдоволення собою, як наслідок - порівняння себе з об'єктом ідеалізації. Отже, у статті розглядаються результати теоретико-емпіричного дослідження особливостей перфекціонізму особистостей, схильних до заздрощів різного ступеню. Метою статті є виклад результатів дослідження співвідношення показників схильності до заздрощів та перфекціонізму особистостей. Заздрісність ми розглядаємо як усталену властивість особистості, спричинену частим порівнянням себе з іншими не на свою користь, що характеризується суб'єктивним відчуттям зниження самоцінності та виявляється пристрасним бажанням заволодіти перевагами об'єкту порівняння. Перфекціонізм розглядається як прагнення бути досконалим, бездоганним у всьому. Для діагностики заздрісності використовувалися спеціально створені тест-опитувальник «Диференціальна діагностика схильності особистості до заздрощів» (ДІЗА) та опитувальник «Соціальні настанови особистості відносно заздрощів» О. П. Саннікової, А. Ф. Лісовенко. Задля діагностики перфекціонізму було застосовано методику «Багатовимірна шкала перфекціонізму» П. Хьюїтта і Р. Флетта. У резульатті дослідження було отримано значимі кореляційні взаємозв'язки додатного знаку між показниками заздрісності та перфекціонізму. Розглянуто та проаналізовано профілі показників перфекціонізму в групах досліджуваних з максимальними та мінімальними значеннями загального показника заздрощів. Емпірично доведено та теоретично обгрунтовано, що заздрісним особистостям властивий невротичний, соціально орієнтований та приписаний перфекціонізм, 
подібний до соціальної настанови, надмірне прагнення до недосяжного, а часом навіть хибного ідеалу. Такі особистості переконані в тому, що інші люди висувають до них надзвичайно високі та нереалістичні очікування і стандарти, відповідати яким дуже важко чи неможливо, але необхідно, щоб заслужити схвалення і прийняття, уникнути негативної оцінки. Їх більше турбує не сам результат певної справи, а прийняття, схвалення, захоплення, самоствердження, які вони можуть отримати, успішно справляючись з роботою або досягаючи в чомусь досконалості. Вони є залежними від зовнішніх оцінок та стандартів і часто розчаровуються у досягнутому.

Ключові слова: заздрість, заздрісність, перфекціонізм, властивість особистості, особистість.

Submitted on January, 20, 2017

Reviewed by Doctor of Psychology O. Sannikov

УДК: $316.647 .5: 373.02$

DOI: https://doi.org/10.24195/2414-4665-2017-1-12

\begin{abstract}
Світлана Павлівна Яланська,
доктор психологічних наук, професор,

завідувач кафедри загальної, вікової та практичної психології,
\end{abstract}

Ніна Михайлівна Атаманчук,

кандидат психологічних наук, доцент

кафедри загальної, вікової та практичної психології,

Полтавський наиіональний педагогічний університет імені В. Г. Короленка, вул. Остроградського, 2, м. Полтава, Украӥна

\section{ПСИХОЛОГІЯ ФОРМУВАННЯ ТОЛЕРАНТНОГО СЕРЕДОВИЩА В УМОВАХ НОВОЇ УКРАЇНСЬКОЇ ШКОЛИ}

Стаття присвячена актуальній проблемі психологї формування толерантного освітнього середовища. На сьогодні об'єднання суспільства можливе лише на засадах толерантності, щзо базується на приниипах миру, милосердя, взаєморозуміння та взаємодопомоги. Тож розвиток толерантної особистості має здійснюватися в освітніх закладах різних рівнів. Мета статті полягає у розкритті психолого-педагогічних і тренінгових засобів створення толерантного освітнього середовища, визначенні основних иляхів його формування 6 новій українській школі. Під толерантністю особистості ми розумісмо доброзичливе та терпиме ставлення до оточуючих і навколишніх подій, щзо не порушують прав людини й не завдають шкоди навколишньому середовищу. Визначено, щуо структура толерантності особистості базується на основних структурних компонентах: когнітивному (знання про об'єкти і ситуації життєдіяльності, щзо є результатом набуття індивідуального досвіду); емоційному (емоційні стани, які передують виникненню поведінкового компоненту, сприяючи систематизації знань і появі певної поведінки); поведінковому (призводить до актуалізації елементарних фіксованих установок, ціннісних орієнтацій та етнічних цінностей). За результатами теоретичних (теоретичний аналіз, синтез, індукиія, абстрагування, порівняння, узагальнення, систематизачія) та емпіричних (анкетування, бесіда) методів дослідження розроблено програму розвитку толерантності, шчо спрямована на створення толерантного середовища, партнерської взаємодії між учасниками навчально-виховного процесу, мотивацію до творчої самореалізації, доброзичливого, терпимого ставлення до оточуючих; розвиток позитивного мислення; розкриття здібностей і можливостей особистості в освітньому середовищі.

Ключові слова: толерантність, толерантне середовище, нова украӥнська школа, учнівська молодь, студентська молодь, психолого-педагогічні засоби, тренінгові засоби.

\section{Постановка проблеми}

Сучасні суспільні зміни політичного, економічного, освітнього характеру можливі лише на принципах взаєморозуміння, взаємодопомоги, терпимості та солідарності. Згідно 3 концепцією «Нова українська школа», що ухвалена рішенням колегії $\mathrm{MOH}$ від 27.10.2016 року, освітні заклади мають працювати на основі «педагогіки партнерства», що передбачає повагу до особистості, довіру у відносинах, соціальне партнерство [2]. Тож функціонування нової українсь- кої школи неможливе без формування толерантного навчально-виховного середовища.

У свідомості учнівської, студентської молоді повинно мати місце розуміння та визнання факту необхідності розвитку соціальних відносин, в основі яких має бути терпимість, справедливість, солідарність, відмова від насилля і нанесення шкоди навколишньому середовищу. 